\title{
Effects of Lead Sulfate on Genetic and Epigenetic Changes, and Endogenous Hormone Levels in Corn (Zea mays L.)
}

\author{
Filiz Aygun Erturk', Guleray Agar ${ }^{2 *}$, Esra Arslan², \\ Gokce Nardemir ${ }^{3}$, Murat Aydin ${ }^{4}$, M. Sinan Taspinar ${ }^{5}$ \\ 'Department of Molecular Biology, Faculty of Science, Avrasya University, Trabzon, Turkey \\ ${ }^{2}$ Department of Biology, Faculty of Science, Ataturk University, Erzurum 25240, Turkey \\ ${ }^{3}$ Department of Molecular Biology and Genetics, Faculty of Science, Agri İbrahim Cecen University, Agri, Turkey \\ ${ }^{4}$ Department of Field Crops, Faculty of Agriculture, Ataturk University, Erzurum, Turkey \\ ${ }^{5}$ Department of Agricultural Biotechnology, Faculty of Agriculture, Ataturk University, Erzurum, Turkey
}

\author{
Received: 23 March 2014 \\ Accepted: 8 July 2014
}

\begin{abstract}
In this research we aimed to evaluate DNA damage levels, DNA methylation, and protein and pytohormone level changes in corn seedlings (Zea mays L.) exposed to 5, 10, 20, and $40 \mathrm{mM}$ concentrations of lead sulfate solution $\left(\mathrm{PbSO}_{4}\right)$. The results showed that all concentrations of the test material caused a decreasing mitotic index, genomic template stability (GTS), and soluble protein levels, but increased RAPDs profile changes (DNA damage) and DNA hypermethylation. Moreover, in the HPLC (high-pressure liquid chromatography) analyses, it was also observed that $\mathrm{Pb}$ contamination caused a decrease in the growth-promoting hormones including gibberellic acid (GA), zeatin (ZA), and indole acetic acid (IAA) levels, in contrast to increasing the absisic acid (ABA) level. The results of this experiment have clearly shown that $\mathrm{Pb}$ has a significant impact on the epigenetic mechanisms as well as its genotoxic effects. Some of phytohormone decreases (GA, ZA and IAA) and especially increasing ABA levels under Pb stress may be a part of the defense system against stress.
\end{abstract}

Keywords: lead sulfate, DNA damage, DNA methylation, total soluble protein level, phytohormones

\section{Introduction}

Heavy metal contamination is considered one of the most important problems for the environment and human health because heavy metals are pollutants that cannot be degraded to nontoxic forms [1]. Among the toxic metal contaminants, lead $(\mathrm{Pb})$ pollution can occur from mining and smelting activities, $\mathrm{Pb}$-containing paints, gasoline, and explosives, as well as from the disposal of municipal sewage sludges enriched with $\mathrm{Pb}[2,3]$. When the soil is

*e-mail: gagar@atauni.edu.tr lead-contaminated, plants take up lead via their root systems [4]. $\mathrm{Pb}$ is known as one of the nonessential metals for plants, and there are a number of reports on its toxic effects such as decreasing on germination rate, growth, and dry mass of roots and shoots [5] reduction in cell division [6], and inhibition of photosynthetic activity besides its genotoxic [3] and epigenetic effects [7, 8]. The genotoxic effect of $\mathrm{Pb}$ on plants has been shown by using various genotoxic tests such as comet, micronucleus, or chromosome aberration assays in several studies [6,9]. However, little is known about the effects of lead on DNA methylation changes in plants. Few papers have shown that DNA hyper- 
metylation in wheat can occur via $\mathrm{Pb}$ treatment $[7,8] . \mathrm{Pb}$ effect on DNA methylation still needs more research. As an epigenetic mechanism, DNA methylation plays an important role in regulating gene expression in plants and in regulating the activity of transposable elements [10] and in paramutation [11-13]. DNA methylation in specific gene expression patterns under epigenetic control are reversible and may show transgenerational inheritance [14, 15]. Epigenetic control for plant adaptation under stress is vital and necessary. DNA methylation exists in virtually all organisms. In eukaryotes (especially methylation) it occurs predominantly on the cytosine residues in symmetrical sequences, such as $\mathrm{CpG}$ and $\mathrm{CpNpG}$. Under normal conditions, the ratio of methylated to total cytosines varies from $20 \%$ to $30 \%$ in plants [16]. Cytosine methylation is numerous polymorphisms and DNA sequence polymorphisms between different plant genotypes [17, 18]. Additionally, plant growth regulators response protect plants against DNA methylation and oxidative stress generated by different stress. Several recent studies have shown that their levels change significantly in plants under a variety of stress conditions including water, salt, temperature, heavy metal, and viral infection $[4,19,20]$. Thus, in the current study we aimed to determine the genotoxic potential of lead and its epigenetic effects on maize seedlings by using the RAPD, mitotic index, and CRED-RA techniques. Furthermore, the relations among genetic-epigenetic and physiological parameters were also determined by measuring the changes in total soluble protein content and phytohormones levels.

\section{Materials and Methods}

\section{Plant Material, Inclusion of Lead Sulfate and Germination}

Zea mays L. seeds were obtained from the Department of Field Crops, Faculty of Agriculture, Ataturk University (Turkey), and were used in this study as plant material. Seeds were surface-sterilized with $0.5 \%$ sodium hypochlorite solution for $10 \mathrm{~min}$ and then washed with sterilized water three times. 15 seeds in four replications were placed in $15 \mathrm{~cm}$ diameter sterile petri dish with two layers of filter paper and then treated with different lead sulfate $\left(\mathrm{PbSO}_{4}\right)$ concentrations $(5,10,20,40 \mathrm{mM})$. Tap water was used as control group. The seeds were allowed to germinate at $25 \pm 1^{\circ} \mathrm{C}$ and $50 \%$ humidity in a $16 \mathrm{~h}$ photoperiod.

\section{Cytological Analysis}

When root length reached approximately $1.5-2 \mathrm{~cm}$, ten root tips (2-3 $\mathrm{mm})$ in each treatment group were excised and transferred to colchicine solution $(0.15 \%)$ for $2 \mathrm{~h}$ and fixed in farmer's solution $(3: 1 ; 95 \%$ ethanol:glacial acetic acid) for $24 \mathrm{~h}$ at $4^{\circ} \mathrm{C}$. Root tips were then hydrolyzed with $1 \mathrm{~N} \mathrm{HCL}$ for $15 \mathrm{~min}$ at $60^{\circ} \mathrm{C}$. For the observation of cell division, root tips were stained with $2 \%$ aceto-orcein staining for 2-3 $\mathrm{h}$ and then squashed in $45 \%$ glacial acetic acid.
To determine the effect of lead on mitotic index (MI), 3 slides were examined for each treatment and were counted 1500 cell. MI was calculated as the ratio of the number of dividing cells to the total number of cells.

\section{Total Protein Content and SDS-PAGE}

Quantitative estimation of total protein in the ground tissue of roots, shoots, and leaf systems of Z. mays L. seedlings were estimated according to [21]. For protein analysis with SDS-PAGE, protein isolation and purification were carried out as described by $[22,23]$. Polypeptides of proteins were separated in $12.5 \%$ SDS-polyacrylamide gel (PAGE) at $110 \mathrm{~V}$ [24]. The gel was stained with Coomassie brilliant blue.

\section{Phytohormones Analysis}

Cytokinins (t-Zeatin), indole-3-acetic acide (IAA), gibberellic acid (GA), and abscisic acid were analyzed as described by [21, 25-27], with minor modifications.

\section{Genomic DNA Isolation, RAPD, and CRED-RA Analysis}

Leaves were randomly collected from 10 plants for each treatment and were stored at $-80^{\circ} \mathrm{C}$. DNA isolation and purification were carried out as described by [29]. 16 primers were used in RAPD PCR reactions. Sequences $\left(5^{\prime} \rightarrow 3^{\prime}\right)$ of primers are CAGCACCCAC (OPA-13), CACTCTCCTC (OPH-17), TGCCGAGCTG (OPA-2), CAGGCCCTTC (OPA-1), GGTCCCTGAC (OPA-6), ACCAGGTTGG (OPH-14), GAATCGGCCA (OPH-18), GTGGCATCTC (OPY-1), AAGGCTCACC (OPY-6), AGGCAGAGCA (OPY-8), AGTCGCCCTT (OPY-15), GGGCCAATGT (OPY-16), CTCAGTGTCC (OPW-1), GTCCACACGG (OPB-8), CTGGACGTCA (OPW-7), and GGCGGATAAG (OPW-5).

RAPD-PCR reaction contained $25 \mathrm{ng}$ genomic DNA, $400 \mu \mathrm{M}$ dNTP, 10 pmol primer, $2.5 \mathrm{mM} \mathrm{MgCl}_{2}, 1 \mathrm{U}$ Taq DNA polymerase, and 1X PCR buffer (10X) in a total volume of $20 \mu \mathrm{L}$. DNA amplification was carried out in a thermocycler programmed as follows: 1 cycle of $5 \mathrm{~min}$ at $95^{\circ} \mathrm{C}$, 42 cycles of $\left(1 \mathrm{~min}\right.$ at $94^{\circ} \mathrm{C}, 1 \mathrm{~min}$ at $36^{\circ} \mathrm{C}$, and $2 \mathrm{~min}$ at $72^{\circ} \mathrm{C}$ ), 1 cycle of $15 \mathrm{~min}$ at $72^{\circ} \mathrm{C}$. PCR products were analyzed using $1 \%$ agarose gel electrophoresis and visualized with ethidium bromide staining. The sizes of the fragments were estimated based on a DNA ladder of $100 \mathrm{bp}$.

A genomic DNA sample from each treatment was separately digested with HpaII and MspI endonucleases (which cut the sequence 5'-C/CGG-3' with different sensitivity to cytosine methylation; MspI cuts if the inner $\mathrm{C}$ is methylated, whereas HpaII cannot cleave in the presence of methyl groups). After checking digestion on agarose gel, $1 \mu 1$ of each digestion product were amplified with random primers (OPA-1, OPA-2, OPH-18, OPY-6, OPY-15, OPW1, OPB-8, and OPH-17). Amplification and visualization conditions for CRED-RA are the same as described for RAPD analysis. 
Table 1. Pytohormones content, total soluble protein content, and mitotic index in maize exposed to lead.

\begin{tabular}{|c|c|c|c|c|c|c|}
\hline \multirow{2}{*}{$\begin{array}{c}\text { Lead }(\mathrm{pb}) \\
\text { Dose }(\mathrm{mM})\end{array}$} & \multirow{2}{*}{$\begin{array}{c}\text { Total soluble } \\
\text { protein }(\mathrm{mg} / \mathrm{ml})\end{array}$} & \multirow{2}{*}{$\begin{array}{c}\text { Mitotic Index } \\
(\mathrm{MI})\end{array}$} & \multicolumn{4}{|c|}{ Pytohormones $(\mu \mathrm{g} / \mathrm{mL})$} \\
\cline { 4 - 7 } & & $\mathrm{GA}$ & Zeatin & \multicolumn{2}{|c|}{ IAA } & ABA \\
\hline 0 (control) & $3.307^{\mathrm{ab} *}$ & $9.0^{\mathrm{a} *}$ & $363.00 \pm 1.54^{\mathrm{a} *}$ & $2.4 \pm 0.11^{\mathrm{a} *}$ & $20.09 \pm 0.57^{\mathrm{a} *}$ & $6.5 \pm 0.11^{\mathrm{a} *}$ \\
\hline 5 & $3.370^{\mathrm{a}}$ & $4.1^{\mathrm{b}}$ & $284.46 \pm 0.49^{\mathrm{b}}$ & $2.2 \pm 0.17^{\mathrm{ab}}$ & $19.60 \pm 0.05^{\mathrm{a}}$ & $8.8 \pm 0.17^{\mathrm{b}}$ \\
\hline 10 & $3.337^{\mathrm{a}}$ & $3.6^{\mathrm{bc}}$ & $278.70 \pm 0.40^{\mathrm{c}}$ & $2.0 \pm 0.23^{\mathrm{abc}}$ & $18.70 \pm 0.11^{\mathrm{b}}$ & $12.4 \pm 0.11^{\mathrm{c}}$ \\
\hline 20 & $3.240^{\mathrm{bc}}$ & $2.6^{\mathrm{bc}}$ & $265.73 \pm 0.33^{\mathrm{d}}$ & $1.7 \pm 0.11^{\mathrm{bc}}$ & $18.60 \pm 0.23^{\mathrm{b}}$ & $13.9 \pm 0.23^{\mathrm{d}}$ \\
\hline 40 & $3.213^{\mathrm{c}}$ & $2.0^{\mathrm{c}}$ & $210.23 \pm 0.01^{\mathrm{e}}$ & $1.5 \pm 0.23^{\mathrm{c}}$ & $16.20 \pm 0.02^{\mathrm{c}}$ & $17.2 \pm 0.11^{\mathrm{e}}$ \\
\hline
\end{tabular}

*The difference between values with the same letter in each column is not significant at the level 0.05

RAPD patterns were evaluated using the Total Lab TL120 computer software. Genomic template stability (GTS, \%) was calculated as follows:

$$
G T S=100-(100 \times a / n)
$$

...where $a$ in formula is the average number of polymorphic bands detected in each treated sample, and $n$ is the number of total bands in the control. Polymorphisms in RAPD profiles included the disappearance of a normal band and appearance of a new band compared with the control. The average was calculated for each experimental group. To compare the sensitivity of each parameter, changes in these values were calculated as a percentage of their control (set to $100 \%)$. The average number of polymorphisms ( $\%$ ) was calculated for each dose to realize CRED-RA analysis. To calculate the number of polymorphisms (\%), the following formula was used $100 \times a / n$.

\section{Statistical Analysis}

Mitotic index, total protein content, and phytohormone content were tested using SPSS statistical according to complete random design, and mean separation was performed by Duncan's multiple test at 0.05 level.

\section{Results}

\section{Changes of Mitotic Index (MI) Value in Maize Seedlings Subjected to Various $\mathrm{Pb}$ Concentrations}

$\mathrm{Pb}$ decreased significantly the MI of Zea mays root meristems when compared with control as seen in Table 1, and the mitotic index decreased progressively with increasing $\mathrm{Pb}$ concentration. Such a decrease was found to be statistically significant $(\mathrm{P}<0.05)$. All concentrations of $\mathrm{Pb}$ used in this study increased the frequencies of abnormalities such as C-mitosis, chromosomal stickiness, and anaphase and telophase bridges involving one or more chromosome micronuclei and fragments.

\section{Total Protein Content}

All concentrations of $\mathrm{Pb}$ affected the total proteins, and the protein content decreased with increasing $\mathrm{Pb}$ concentrations at a statistically significant level $(\mathrm{P}<0.05)$ (Table 1). Also, the proteins obtained from the seedlings of maize treated with different concentrations of $\mathrm{Pb}$ were investigated by sodium dodecyl sulfate-polyacrylamide gel electrophoresis (SDS-PAGE). The results showed that little changes are available in the total protein band pattern. These changes are only characterized by variation in band intensity (Fig. 1).

\section{RAPD Analysis}

In total, 40 10-mer priming oligonucleotides were used in RAPD and 16 of them were selected for their stable results and produced the total number of 512 bands. Table 2 represents the summary of all polymorphic bands in RAPD profile and Fig. 2 presents all RAPD bands of the select 4 primers. Compared with the PCR products obtained from the control DNA, $\mathrm{Pb}$ treatments resulted in apparent changes in RAPD patterns. These changes are characterized by variation in band intensity, loss of normal bands, or appearance of new bands (Table 2 and Fig. 2).

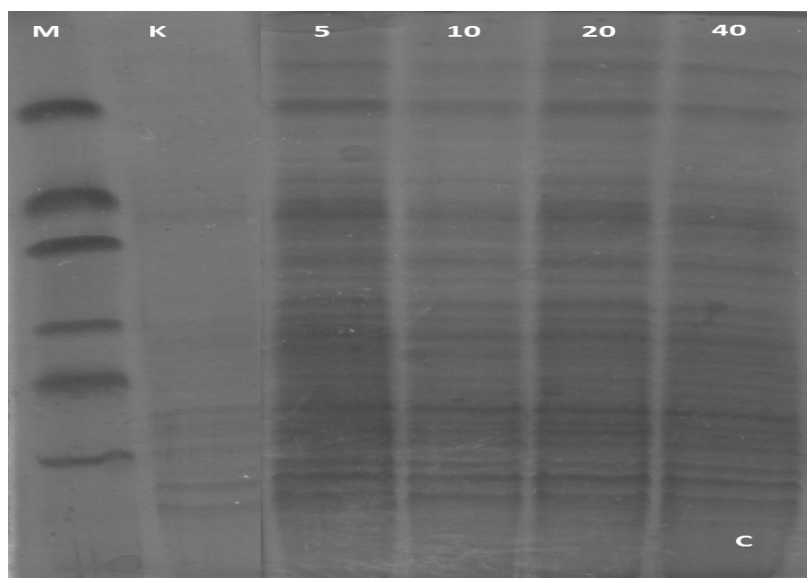

Fig. 1. Comparison of total soluble protein levels in maize seedlings exposed to different concentrations of $\mathrm{Pb}$. 
Table 2. The number of bands in control and disappearance (-), and/or appearance $(+)$ of DNA bands with molecular sizes (base pair, bp) for all the primers in the roots of $\mathrm{Pb}$ treated maize seedlings.

\begin{tabular}{|c|c|c|c|c|c|c|}
\hline \multirow{2}{*}{ Primers } & \multirow{2}{*}{ Control } & \multirow{2}{*}{$+/-$} & \multicolumn{4}{|c|}{ Lead $(\mathrm{Pb})(\mathrm{mM})$} \\
\hline & & & 5 & 10 & 20 & 40 \\
\hline \multirow{2}{*}{ OPA-13 } & \multirow{2}{*}{7} & + & 263 & $629,584,516,266$ & 516,263 & $629,516,266$ \\
\hline & & - & 424 & & & 228 \\
\hline \multirow{2}{*}{ OPH-17 } & \multirow{2}{*}{12} & + & -- & -- & -- & -- \\
\hline & & - & -- & -- & -- & -- \\
\hline \multirow{2}{*}{ OPA-2 } & \multirow{2}{*}{8} & + & 646 & $1063,646,178$ & 646,178 & $1063,646,178$ \\
\hline & & - & $718,392,314$ & 718 & 718,392 & 718,392 \\
\hline \multirow{2}{*}{ OPA-1 } & \multirow{2}{*}{11} & + & -- & -- & -- & -- \\
\hline & & - & 382 & -- & -- & -- \\
\hline \multirow{2}{*}{ OPA-6 } & \multirow{2}{*}{9} & + & 765,457 & $765,747,666,457$ & $765,747,666,457$ & $765,747,666,457$ \\
\hline & & - & $710,639,419$ & 639,419 & 639,419 & 639,419 \\
\hline \multirow{2}{*}{ OPH-14 } & \multirow{2}{*}{5} & + & 367,231 & 231 & 231 & 231 \\
\hline & & - & 427,190 & $427,400,263,190$ & $190,263,427,400$ & $190,263,427,400$ \\
\hline \multirow{2}{*}{ OPH-18 } & \multirow{2}{*}{5} & + & 794,342 & 342 & 794,342 & 794,342 \\
\hline & & - & $\begin{array}{c}765,732,506,279 \\
188\end{array}$ & $765,732,506,279,188$ & $\begin{array}{c}765,732,506,279 \\
188\end{array}$ & $\begin{array}{c}765,732,506,279 \\
188\end{array}$ \\
\hline \multirow{2}{*}{ OPY-6 } & \multirow{2}{*}{10} & + & $797,622,548$ & $797,622,548$ & $797,622,548$ & $797,622,548$ \\
\hline & & - & 750 & 750 & 750 & 750 \\
\hline \multirow{2}{*}{ OPY-1 } & \multirow{2}{*}{7} & + & 329 & & 329 & \\
\hline & & - & 643 & 643 & 643 & 643 \\
\hline \multirow{2}{*}{ OPY-8 } & \multirow[b]{2}{*}{8} & + & 603 & -- & 603 & 603,434 \\
\hline & & - & 770,720 & $\begin{array}{c}932,832,770,720,543, \\
334\end{array}$ & $\begin{array}{c}932,832,770,543, \\
334\end{array}$ & $\begin{array}{c}932,832,770,543, \\
334\end{array}$ \\
\hline \multirow{2}{*}{ OPY-15 } & \multirow{2}{*}{12} & + & 302 & 302 & 302 & 617,325 \\
\hline & & - & -- & -- & 260 & 260 \\
\hline \multirow{2}{*}{ OPY-16 } & 10 & + & -- & -- & -- & -- \\
\hline & & - & 276,255 & 255 & $504,276,255$ & 297,255 \\
\hline DDW & 11 & + & 432,328 & 551 & -- & -- \\
\hline & & - & -- & -- & -- & -- \\
\hline 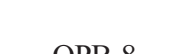 & 6 & + & -- & -- & -- & -- \\
\hline & & - & -- & -- & -- & -- \\
\hline & & + & 409 & -- & 409 & 542 \\
\hline & & - & 372 & 372 & 372 & 372 \\
\hline & & + & 521,333 & $521,407,386,333$ & $521,386,333$ & $521,386,333$ \\
\hline & & - & -- & -- & -- & -- \\
\hline Total band & 137 & & 41 & 44 & 46 & 49 \\
\hline Polymorphism & & & 29.92 & 32.11 & 33.58 & 35.77 \\
\hline GTS value & & & 70.08 & 67.89 & 66.42 & 64.23 \\
\hline
\end{tabular}


Table 3. CRED-RA band amounts in various $\mathrm{Pb}$ concentrations and polymorphism \%.

\begin{tabular}{|c|c|c|c|c|c|}
\hline \multirow{2}{*}{ Primers } & \multirow{2}{*}{$\mathrm{H} / \mathrm{M}$} & \multicolumn{4}{|c|}{ Lead $(\mathrm{Pb})(\mathrm{mM})$} \\
\hline & & 5 & 10 & 20 & 40 \\
\hline \multirow{2}{*}{ OPA-1 } & $\mathrm{H}$ & 0 & 33.3 & 33.3 & 44.4 \\
\hline & $\mathrm{M}$ & 50 & 25 & 0 & 50 \\
\hline \multirow{2}{*}{ OPA-2 } & $\mathrm{H}$ & 37.5 & 62.5 & 25 & 42.8 \\
\hline & $\mathrm{M}$ & 22.2 & 42.8 & 40 & 50 \\
\hline \multirow{2}{*}{ OPH-18 } & $\mathrm{H}$ & 42.8 & 40 & 40 & 44.4 \\
\hline & $\mathrm{M}$ & 37.5 & 44.4 & 40 & 44.4 \\
\hline \multirow{2}{*}{ OPY-6 } & $\mathrm{H}$ & 40 & 60 & 100 & 100 \\
\hline & M & 50 & 25 & 100 & 75 \\
\hline \multirow{2}{*}{ OPY-15 } & $\mathrm{H}$ & 28.5 & 33.3 & 42.8 & 37.5 \\
\hline & M & 25 & 33.3 & 33.3 & 55.5 \\
\hline \multirow{2}{*}{ OPW-1 } & $\mathrm{H}$ & 11.1 & 25 & 100 & 100 \\
\hline & $\mathrm{M}$ & 42.8 & 100 & 37.5 & 37.5 \\
\hline \multirow{2}{*}{ OPB-8 } & $\mathrm{H}$ & 40 & 55.5 & 60 & 42.8 \\
\hline & $\mathrm{M}$ & 33.3 & 50 & 62.5 & 83.3 \\
\hline \multirow{2}{*}{ OPH-17 } & $\mathrm{H}$ & 50 & 57.1 & 100 & 37.5 \\
\hline & $\mathrm{M}$ & 66.6 & 14.2 & 66.6 & 37.5 \\
\hline \multirow{2}{*}{ Avarage } & $\mathrm{H}$ & 31.2 & 45.8 & 62.6 & 56.1 \\
\hline & $\mathrm{M}$ & 40.9 & 41.8 & 47.4 & 54.1 \\
\hline
\end{tabular}

Some primers resulted in alteration of a few amplification products (OPW-5), while others (OPY-8) gave more complicated patterns of gains or losses. After $\mathrm{Pb}$ treatment, in total 137 normal RAPD bands from the control disappeared. In addition, 86 new bands appeared in all concentrations of $\mathrm{Pb}$ treatment. Polymorphism value was calculated as $29.92,32.11,33.58$, and $35.77 \%$ for $5,10,20$, and $40 \mathrm{mM}$ doses, respectively. Based on these alterations, GTS values were calculated as $70.08,67.89,66.42$, and $64.23 \%$, respectively (Table 2). It was observed that GTS values decreased with increased $\mathrm{Pb}$ concentrations.

\section{CRED-RA Analysis}

For CRED-RA analysis only eight oligonucleotide (OPA-1, OPA-2, OPW-1, OPY-6, OPB-8, OPY-15, OPH17, OPH-18) products used for RAPD analyzing gave specific and stable bands (Fig. 3). Compared to the PCR prod-
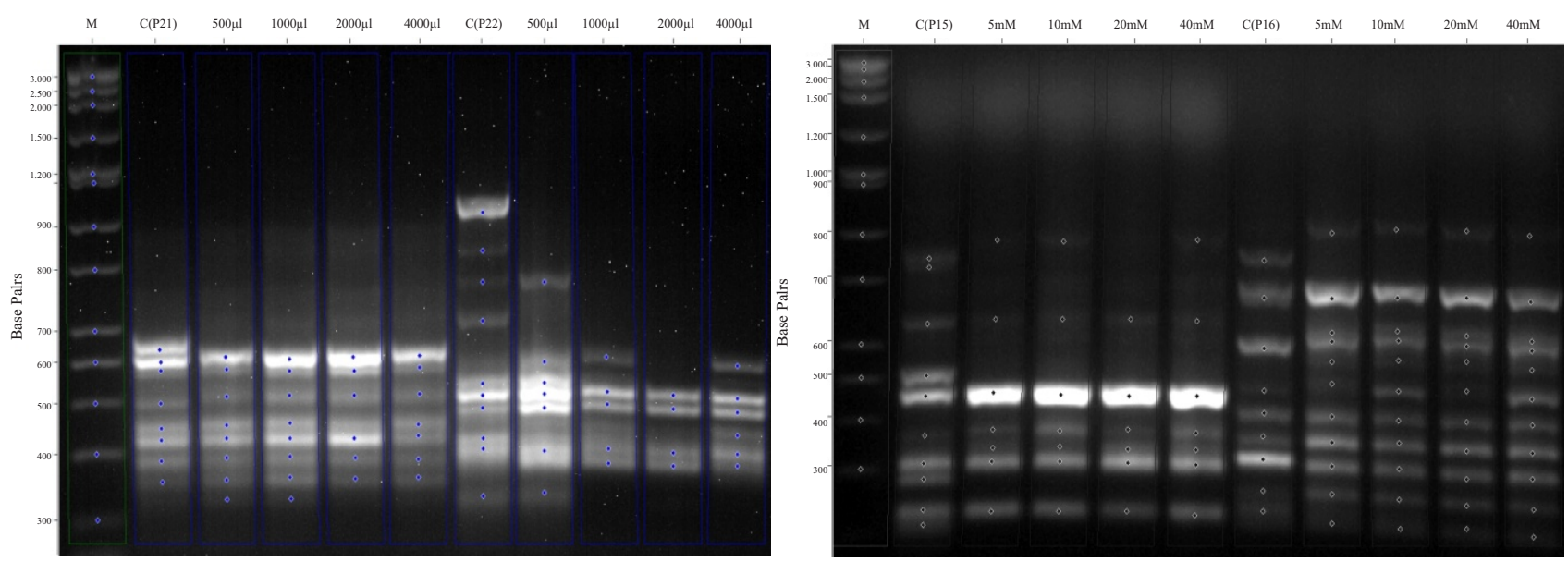

Fig. 2. Randomly amplified polymorphic DNA profiles of Pb-exposed and nonexposed Zea mays seedlings with primers of OPY-6, OPY-8, OPH-18, and OPY-1. 
ucts obtained from the control DNA, dose-related DNA hypermethylation was detected. This ranged from a net hypermethylation of $40.9 \%$ in plants grown in the presence of the $5 \mathrm{mM}$ of $\mathrm{PbSO}_{4}$ to $54.1 \%$ in plants grown with the highest concentration methylation increase (Table 3).

\section{Changes of Pytohormone levels in Maize Seedling Subjected to Various $\mathrm{Pb}$ Concentrations}

The alterations of pytohormone level maize seedlings are presented in Table 1. ABA content in seedlings increased noticeably $(\mathrm{P} \leq 0.05)$ compared with the control plant, let alone the increase of $\mathrm{Pb}$ concentrations following 7 days as seen in Table 1. On the other hand, Z, GA, and IAA content decreased with the increased concentrations of $\mathrm{Pb}$ compared with the control seedlings $(\mathrm{P} \leq 0.05)$. These results were also in a clear dose-dependent manner.

\section{Discussion}

Some research has determined that contamination with $\mathrm{Pb}$ reduces $\mathrm{MI}$ activity and causes mitosis abnormalities such as C-mitosis, chromosomal stickiness, anaphase, and telophase bridges involving one or more chromosome micronuclei and fragments in plant species $[6,9]$. The inhibition of mitotic activity and production of several aberrations caused by $\mathrm{Pb}$ treatment have been explained as being the effect of the treatment on DNA synthesis and its action as an enzymatic inhibitor of the enzyme system required for the chain reaction of DNA synthesis. Our results revealed that $\mathrm{Pb}$ treatment causes an increase in chromosomal aberration frequencies and a decrease in MI levels. Besides, our study used RAPD for evaluation of genotoxic effects of $\mathrm{Pb}$. Recently, DNA fingerprinting has offered a useful biomarker assay in genotoxicity [30]. It is suggested that after proper optimization, especially the RAPD as a reliable, sen- sitive, and reproducible assay, has the potential to detect a wide range of DNA damage (e.g. DNA adducts, DNA breakage) as well as mutations (point mutations and large rearrangements) and therefore can be applied to genotoxicity and carcinogenesis studies [31]. Our results showed that all concentrations of $\mathrm{Pb}$ caused RAPD profile changes. RAPD profile changes can induce a range of DNA damage such as single and double-strand breaks, DNA-protein cross-links, point and deletion mutations, 8-hydroxyguanine, even bulky adducts, complex chromosomal rearrangements and homologous recombinations [32]. In a previous study, similar results have also been obtained [3]. A decreasing GTS value, regarded as an indication of the RAPD profile changes, has been observed with increasing $\mathrm{Pb}$ concentrations. Previous studies have shown GTS value decreasing the induced effect of genotoxins [3, 33-35].

In addition to genetic damage via both oxidative and nonoxidative (DNA adducts) mechanisms, metals can also cause significant changes in DNA methylation and histone modifications, leading to epigenetic silencing or reactivation of gene expression. Recently, several studies have shown that the same heavy metals such as $\mathrm{Cd}, \mathrm{Pb}, \mathrm{Co}, \mathrm{Ni}$, and $\mathrm{Zn}$ cause changes in DNA methylation. Ge et al. have shown that $\mathrm{Pb}$ contamination caused DNA hypermethylation in rice and wheat [7]. These findings are in accordance with our results. Besides, higher concentrations of $\mathrm{Pb}$ have demonstrated that it causes DNA hypomethylation by decreasing DNA methyltransferases, DNMT1, and DNMT3A, reduction in post translationally modified histones such as H3K9ac, H4K8ac, H4K12ac, and H3K4me2 in adult primates [36].

In addition, we investigated the adverse effects of $\mathrm{Pb}$ on maize seedlings using protein analysis. The results demonstrated that all concentrations of $\mathrm{Pb}$ have significantly changed the protein patterns of the seedlings when compared with control as seen in Table 1 . Such a decrease was found to be statistically significant $(p<0.05)$. Results of

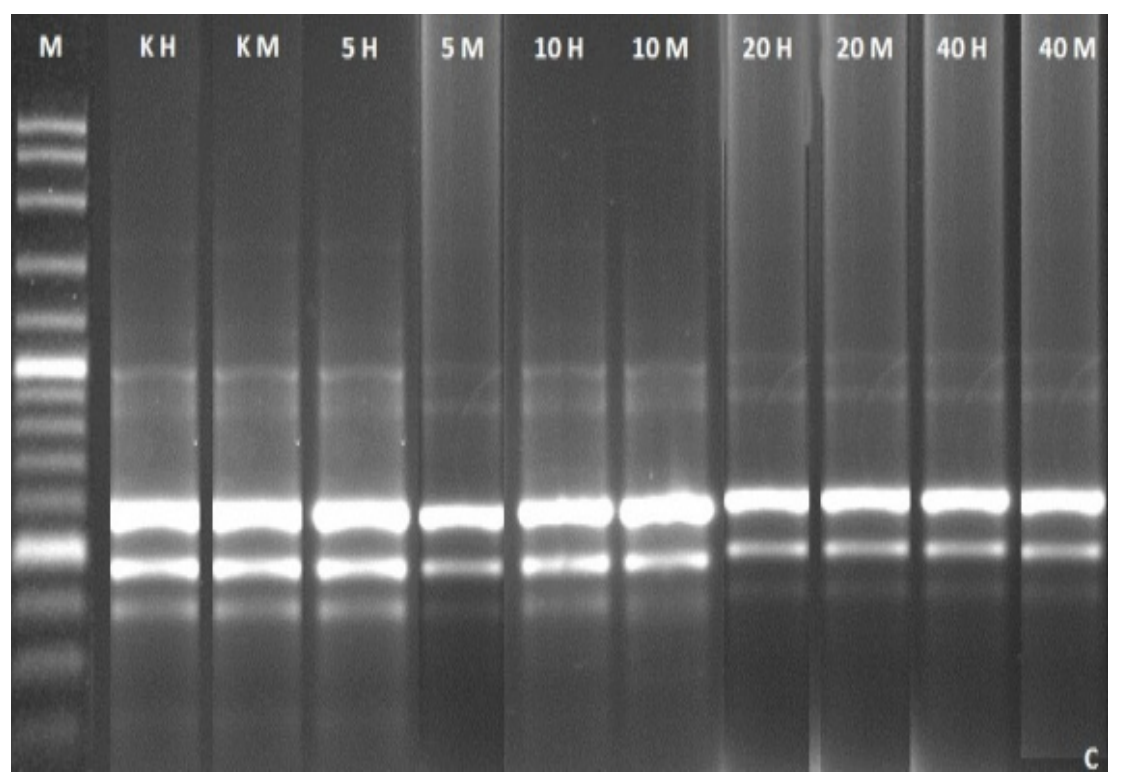

Fig. 3. Coupled restriction enzyme digestion-random amplification (CRED-RA) profiles of Pb-exposed and nonexposed Zea mays seedlings with primers of OPY-15 (M - Marker, K - Control, H - HpaII, M - MspI). 
protein electrophoresis showed that there was a change in the profiles of protein bands. Changes in protein band profiles may cause point mutations, genetic and chromosomal rearrangements, deletion, insertions, and methylation in DNA. Also, a decrease in total protein levels can be suggested as one of the mechanisms for their genotoxic effects in a cell. On the other hand, the total soluble protein content of root tips of maize seedlings (as an important indicator of reversible or irreversible changes in the epigenetic mechanism), exhibited a positive correlation with $\mathrm{Pb}$ concentrations.

In this study, the effects of $\mathrm{Pb}$ on phytohormones levels also has been reported. Our results showed that $\mathrm{Pb}$ caused a decrease in GA, Z, and IAA levels and an increase in ABA in maize seedlings. The degree of these effects was mostly dependent on the concentration of $\mathrm{Pb}$. GAs, Z, and IAA stimulate growth in plants. These phytohormones are synthesized in unstressed conditions and their effects cause growth events in plants. In contrast, $\mathrm{ABA}$ is growth inhibitory and it has been well known as a "stress hormone" in plants. This means that the synthesis of ABA increases especially during stress conditions in the leaves, and it moves to all plant parts to inhibit growth and protect the plant against biotic and abiotic stresses. That is why we think that the levels of phytohormones stimulating growth (GA, Z, and IAA) decreased while ABA synthesis increased in the seedlings. It has been reported that $\mathrm{ABA}$ encourages activity of the alternative respiration pathway, which is related to preventing the formation of reactive oxygen species (ROS) in plants [37]. The ROS levels increase in any stress conditions and cause oxidative stress. In this situation, it is possible to say that ABA synthesis increases to reduce oxidative damage in plants. In addition it has been well known that ABA causes synthesis of some new protein types, inhibits some proteins, and also increases and decreases the synthesis of some proteins that synthesize under stress conditions in plant cells [33, 38, 39]. This means that ABA may play a role in the change of the gene expression model by epigenetic mechanisms in plants. These findings are in accordance with DNA methylation results, but more information on molecular mechanisms of the role of DNA methylation of ABA in plants is needed.

In summary, when we put together the all results, we may say that $\mathrm{Pb}$ has a genotoxic effect and causes DNA hypermethylation in corn seedlings. RAPD and CRED-RA methods can be used as a useful investigational tool for genetic and epigenetic changes inducing genomic alterations. Because of the stress, the synthesis of ABA increases while GA, Z, and IAA levels decrease to protect against damages to $\mathrm{Pb}$ stress in corn seedlings.

\section{References}

1. HERNANDEZ-ALLİCA J., GARBİSU C., BARRUTİA O., BECERRIL J.M. EDTA-induced heavy metal accumulation and phytotoxicity in cardoon plants. Environ. Exp. Bot., 60, 26, 2007.
2. SHARMA P., DUBEY R.S. Modulation of nitrate reductase activity in rice seedlings under aluminium toxicity and water stress: role of osmolytes as enzyme protectant. J. Plant Physiol., 162, 854, 2005.

3. CENKCI S., CIĞERCİ İ.H., YILDIZ M., OZAY C., BOZDAĞ A., TERZİ H. Lead contamination reduces chlorophyll biosynthesis and genomic template stability in Brassica rapa L. Environ. Exp. Bot., 67, 467, 2010.

4. ATICİ O., AGAR G., BATTAL P. Changes in phytohormone contents in chickpea seeds germinating under lead or zinc stress. Biol. Plantarum, 49, 215, 2005.

5. EKMEKCI Y., TANYOLAC D., AYHAN B. A crop tolerating oxidative stress induced by excess lead: maize. Acta Physiol. Plant., 31, 319, 2009.

6. SAMARDAKIEWICZ S., WOZNY, A. Cell division in Lemna minor roots treated with lead. Aquat. Bot., 83, 289, 2005.

7. GE X.C., ZONG H., ZHAN S.X., CHEN J.C., SUN C.R., CAO, K.M. Cloning and expression analysis of a human putative tumor suppressor gene homologue from rice. Acta Bot. Sin., 44, 562, 2002.

8. LU Y., RONG T., CAO M. Analysis of DNA methylation in different maize tissues. Journal of Genetics and Genomics, 35, 41, 2008.

9. GICHNER T., ZNIDAR I., SZAKOVA J. Evaluation of DNA damage and mutagenicity induced by lead in tobacco plants. Mutat. Res., 652, 186, 2008.

10. MARTIENSSEN R.A., RICHARDS E.J. DNA methylation in eukaryotes. Curr. Opin. Genet. Dev., 5, 234, 1995.

11. Sİ Y., ZHANG C., MENG S., DANE, F. Gene expression changes in response to drought stress in Citrullus colocynthis. Plant Cell Rep., 28, 997, 2009.

12. ZHOU J., WANG X., JIAO Y., QIN Y., LIU X., HE K., CHEN C., MA L., WANG J., XİONG L., ZHANG Q., FAN L., DENG X.W. Global genome expression analysis of rice in response to drought and high-salinity in shoot, flag leaf, and panicle. Plant Mol. Biol., 63, 591, 2007.

13. Lİ X.L., LIN Z.X., NIE Y.C., GUO X.P., ZHANG X.L. Methylation sensitive amplification polymorphism of epigenetics changes in cotton under salt stress. Acta Agronomica Sinica, 35, 588, 2009.

14. ZHAO X., CHAİ Y., LIU B. Epigenetic inheritance and variation of DNA methylation level and pattern in maize intra-specific hybrids. Plant Sci., 172, 930, 2007.

15. WANG C., WANG Z., LUO J., Lİ Q., Lİ Y., AHN K., PROWS D.R., WU R. A model for transgenerational imprinting variation in complex traits. Plos One, 5, e11396, 2010.

16. ZHANG X., YAZAKİ J., SUNDARESAN A., COKUS S., CHAN S.W.L., CHEN H., HENDERSON I.R., SHINN P., PELLEGRINII M., JACOBSEN S.E., ECKER J.R. Genome-wide High-Resolution-Mapping and Functional Analysis of DNA Methylation in Arabidopsis. Cell, 126, 1189, 2006.

17. RUIZ-GARCIA L., CERVERA E.M.T., MARTINEZ-ZAPATER J.M. DNA methylation increases throughout Arabidopsis development. Planta, 222, 301, 2005.

18. AKİMOTO K., KATAKAMI H., KİM H.J., OGAWA E., SANO C.M., WADA Y., SANO H. Epigenetic inheritance in rice plants. Ann. Bot-London, 100, 205, 2007.

19. POSPÍSILOVA J. Participation of phytohormones in the stomatal regulation of gas exchange during water stress. Biol. Plantarum, 46, 491, 2003.

20. ATICI O., AGAR G. Interaction between endogenous plant hormones and a amylase in germinating chichpea seeds under cadmium exposure. Fresen. Environ. Bull., 12, 781, 2003. 
21. TURKER M., BATTAL P., AGAR G., GULlUCE M., SAHIN F., EREZ M.E., YILDIRIM N. Allelopathic effects of plants extracts on physiological and cytological processes during maize seed germination. Allelopathy Journal, 21, 273, 2008.

22. SHULTZ R.W., SETTLAGE S.B., HANLEY-BOWDOIN L. THOMPSON W.F. A trichloroacetic acid-acetone method greatly reduces infrared autofluorescence of protein extracts from plant tissue. Plant Mol. Biol. Rep., 23, 405, 2005.

23. ERTURK F.A., AGAR G., ARSLAN E., NARDEMIR G., SAHIN Z. Determination of genomic instability and DNA methylation effects of $\mathrm{Cr}$ on maize (Zea mays L.) using RAPD and CRED-RA analysis. Acta Physiologiae Plantarum, 36, 1529, 2014.

24. LAEMMLİ U.K. Cleavage of structural proteins during assembly of head of Bacteriophage-T4. Nature, 227, 680, 1970.

25. KURAİSHI S., TASAKİ K., SAKURAİ N., SADATOKU $\mathrm{K}$. Changes in levels of cytokinins in etiolated squash seedlings after illumination. Plant Cell Physiol., 32, 585, 1991.

26. FUJIOKA S., SAKURAİ A., YAMAGUCHİ I., MUROFUSHİ N., TAKAHASHİ N., KAİHARA S., TAKIMOTO A., CLELAND C.F. Flowering and endogenous levels of plant hormones in Lemna species. Plant Cell Physiol., 271, 927, 1986.

27. CAKMAK I., MARSCHNER H., BANGERT F. Effect of zinc nutritional status on growth, protein metabolism and lev- els of indole-3-acetic acid and other phytohormones in bean (Phaseolus vulgaris L.). J. Exp. Bot. 40, 404, 1989.

28. UNYAYAR S., ÇELİK A., ÇEKİÇ F.Ö., GÖZEL A. Cadmium-induced genotoxicity, cytotoxicity and lipid peroxidation in Allium sativum and Vicia faba. Mutagenesis, 21, 77, 2006.

29. Lİ G., QUIROS C.F. Sequence-Related Amplified Polymorphism (SRAP), a new marker system based on a simple PCR reaction: Its application to mapping and gene tagging in Brassica. Theor. Appl. Genet., 103, 455, 2001.

30. SAVVA D. Use of DNA fingerprinting to detect genotoxic effects. Ecotox. Environ. Safe., 41, 103, 1998.
31. ATIENZAR F.A., JHA A.N. The random amplified polymorphic DNA (RAPD) assay and related techniques applied to genotoxicity and carcinogenesis studies: A critical review. Mutat. Res.-Rev. Mutat., 613, 76, 2006.

32. ATIENZAR F.A., CORDİ B., DONKIN M.E. Comparison of ultraviolet-induced genotoxicity detected by random amplified polymorphic DNA with chlorophyll fluorescence and growth in a marine macroalgae, Palnaria palnata. Aquat. Toxicol., 50, 1, 2000.

33. TASPINAR M.S., AGAR G., YILDİRIM N., SUNAR S., AKSAKAL O., BOZARİ S. Evaluation of selenium effect on cadmium genotoxicity in Vicia faba using RAPD. Journal of Food Agriculture and Environment, 7, 857, 2009.

34. TASPINAR M.S., AGAR G., ALPSOY L., YILDİRIM N., BOZARI S. The protective role of Zinc and Calcium in Vicia faba seedlings subjected to cadmium stres. Toxicol. Ind. Health., 27, 73, 2011.

35. SUNAR S., AKSAKAL O., YILDİRIM N., AGAR G., GULLUCE M., SAHIN F. Genetic diversity and relationships detected by FAME and RAPD analysis among Thymus species growing in Eastern Anatolia region of Turkey. Romanian Biotechnological Letters, 144, 267, 2009.

36. BASHA M.R., WEI W., BAKHEET S.A., BENITEZ N., SIDDIQİ H.K., GE Y.W., LAHIRİ D.K., ZAWIA N.H. The fetal basis of amyloidogenesis: Exposure to lead and latent overexpression of amyloid precursor protein and beta-amyloid in the aging brain. J. Neurosci., 25, 823, 2005.

37. OZFIDAN C., TURKAN I., SEKMEN A.H., SECKIN B. Time course analysis of ABA and non-ionic osmotic stressinduced changes in water status, chlorophyll flourescens and osmotic adjustment in Arabidopsis thaliana wild-type (Colombia) and ABA deficient mutant (aba2). Environ. Exp. Bot., 86, 44, 2013.

38. CHINNUSAMY V., GONG Z., ZHU J.K. Abscisic acidmediated epigenetic processes in plant development and stress responses. Journal of Integrative Plant Biology, 50, 1187, 2008.

39. BRADFORD M.M. A rapid and sensitive method for the quantitation of microgram quantities of protein utilizing the principle of protein-dye binding. Anal. Biochem., 72, 248, 1976. 